eEarth Discuss., 1, 63-80, 2006

www.electronic-earth-discuss.net/1/63/2006/

(C) Author(s) 2006. This work is licensed

under a Creative Commons License.

\title{
Horizontal versus vertical plate motions
}

M. Cuffaro, E. Carminati, and C. Doglioni

Dipartimento Scienze della Terra, Università La Sapienza, P. le A. Moro 5, 00185 Roma, Italy

Received: 12 June 2006 - Accepted: 20 June 2006 - Published: 3 July 2006

Correspondence to: C. Doglioni (carlo.doglioni@uniroma1.it)

Horizontal versus vertical plate motions

M. Cuffaro et al.

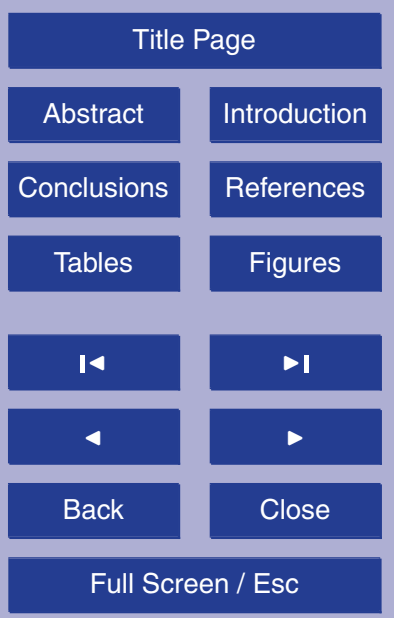

Printer-friendly Version

Interactive Discussion 


\section{Abstract}

We review both present and past motions at major plate boundaries, which have the horizontal component in average 10 to 100 times faster $(10-100 \mathrm{~mm} / \mathrm{yr})$ than the vertical component $(0.01-1 \mathrm{~mm} / \mathrm{yr})$ in all geodynamic settings. The steady faster horizontal velocity of the lithosphere with respect to the upward or downward velocities at plate boundaries supports dominating tangential forces acting on plates. This suggests a passive role of plate boundaries with respect to far field forces determining the velocity of plates. The forces acting on the lithosphere can be subdivided in coupled and uncoupled, as a function of the shear at the lithosphere base. Higher the asthenosphere viscosity, more significant should be the coupled forces, i.e., the mantle drag and the trench suction. Lower the asthenosphere viscosity, more the effects of uncoupled forces might result determinant, i.e., the ridge push, the slab pull and the tidal drag. Although a combination of all forces acting on the lithosphere is likely, the decoupling between lithosphere and mantle suggests that a torque acts on the lithosphere independently of the mantle drag. Slab pull and ridge push are candidates for generating this torque, but, unlike these boundary forces, the advantage of the tidal drag is to be a volume force, acting simultaneously on the whole plates, and being the decoupling at the lithosphere base controlled by lateral variations in viscosity of the low-velocity layer.

\section{Introduction}

Since vertical plate motions are expected to be small compared to the horizontal motions, it is appropriate to use the $v=\omega r$ relation to express the horizontal motions of rigid plates using rotations on a sphere, being $v$ the horizontal plate velocity, $\omega$, the angular velocity and $r$, the Earth's radius. This idealized relationship is only a description of the horizontal motions and does not make any physically meaningful prediction about the relative importance of the vertical component in tectonically deforming zones
$1,63-80,2006$

Horizontal versus vertical plate motions

M. Cuffaro et al.

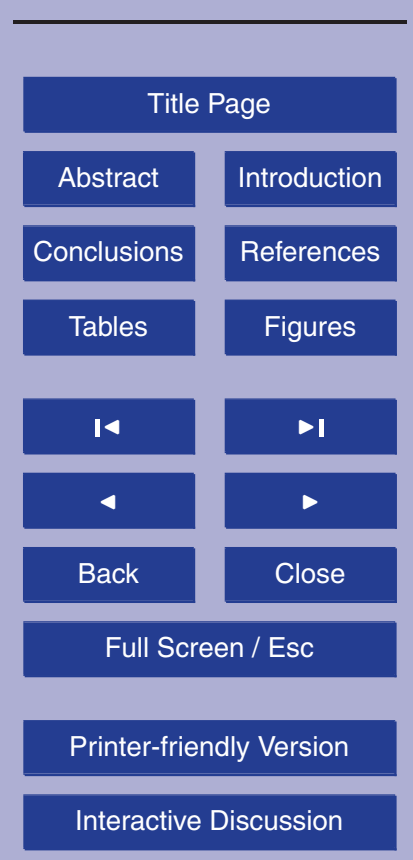


along plate boundaries. We test this idea measuring some present and past horizontal and vertical rates of plate motion. The advent of space geodesy makes it possible to measure present day plate movements (Gordon and Stein, 1992; Heflin et al., 2006) and to test the velocities estimated from NUVEL-1 plate velocity model (DeMets et al., 5 1990). Until recently, the relative contribution of past horizontal and vertical motions had to be inferred indirectly.

Past horizontal movements are recorded by ocean magnetic anomalies, by hotspot tracks, and shortening in the orogens. Along plate boundaries, vertical movements (subsidence or uplift) always accompany horizontal movements. Past subsidence rates 10 in oceanic realms are inferred from bathymetry, which is controlled primarily by the cooling of the lithosphere. Subsidence rates in passive continental margins and in foredeep basins bordering subduction zones are inferred from back-stripping of basin stratigraphy. Uplift of past marine terraces, apatite fission track analyses and metamorphic PTt paths constrain the past uplift and denudation rates in orogenic areas.

Present rates of horizontal and vertical motion give a reliable idea of plate movements in the geological past because, as already noted, present-day velocities roughly match the past rates computed studying the magnetic anomalies of the seafloor spreading (Gordon and Stein, 1992). Along the Tonga trench incredibly fast $(240 \mathrm{~mm} / \mathrm{yr})$ horizontal motions have been described (Bevis et al., 1995).

20 In this paper for the first time we make a worldwide comparison of the horizontal and vertical component of plate motions along plate boundaries, using both present and past rates. We quantify the faster horizontal versus slower vertical motions, and briefly discuss the implications of this observation.

\section{Movements rates}

25 For the present plate motions, our analysis is based on the NASA data set (Heflin et al., 2006), where both horizontal and vertical rates determined from the motion of GPS sites are given in the ITRF2000 reference frame (Altamimi et al., 2002). In that frame-
$1,63-80,2006$

Horizontal versus vertical plate motions

M. Cuffaro et al.

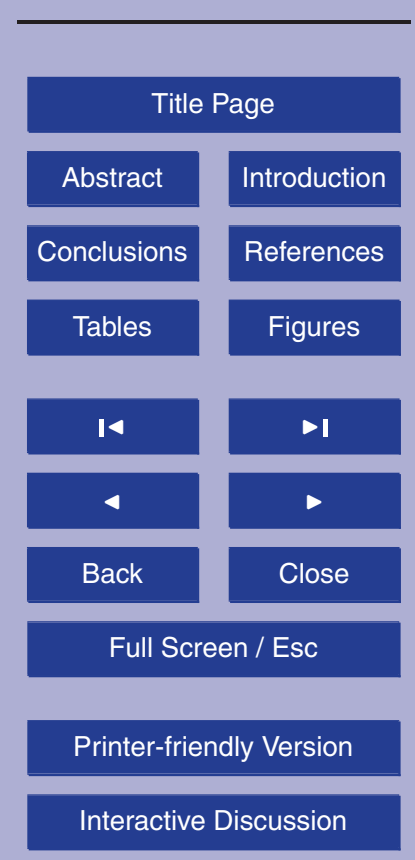


work, the epoch is 1 January 2004 and the reference ellipsoid for latitude, longitude and height is WGS84. Both horizontal and vertical motions are obtained from least squares methods, using GPS time series over time periods of the order of years. In this paper we are interested in evaluating differences between horizontal and vertical 5 plate motions using an official data set, as the NASA one (Heflin et al., 2006). Regardless the goodness of the solutions of plate motions from GPS data, we chose data proposed by Heflin et al. (2006) to have the most updated information about vertical plate motion. For this reason, data utilized here are referred to April 2006.

Plate boundaries accommodate plate motions, and can be even several hundreds $10 \mathrm{~km}$ wide (e.g., Gordon, 2000). Therefore horizontal plate motion between two plates is best evaluated using sites located intraplate, far from plate boundaries. Conversely, motions from the sites located along the plate boundaries better indicate entities of vertical components.

For the purpose to make a comparison between horizontal and vertical rates along different plate margins, we selected GPS stations located on boundaries or as close as possible, and we considered the vertical rate (Heflin et al., 2006) with a negative sign for subsidence and positive for uplift (Table 1).

Every GPS station was also chosen for computing horizontal relative plate motions. In each point we obtained the horizontal velocity through the relative angular velocities and Euler poles of pairs of plates sharing a boundary, using the kinematic parameters of the model REVEL (Sella et al., 2002).

Because we are interested in investigating horizontal relative plate motions along boundaries, we preferred to use a plate motion model (e.g. REVEL), estimated with GPS data, instead of the use of the single time series. Since Sella et al. (2002) used a much more extensive space geodetic dataset to construct their model for recent plate velocities and a robust statistical approach to estimate the uncertainties of the motion rates, this choice guarantees an accurate evaluations of the horizontal relative motion.

Moreover, the use of REVEL model ensures that the calculated relative horizontal motion is not affected by local stress release along plate margins, because motion of

Horizontal versus vertical plate motions

M. Cuffaro et al.

Title Page

Abstract Introduction

Conclusions References

Tables Figures

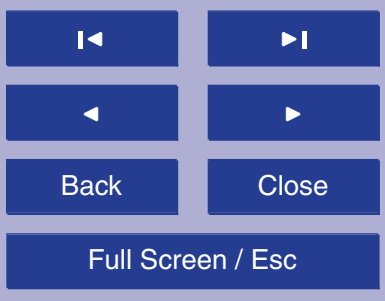

Printer-friendly Version

Interactive Discussion 
plates and crustal blocks are evaluated choosing sites located $>100 \mathrm{~km}$ from significant plate boundary zone-related seismicity.

The use, here, of the REVEL plate kinematic model do not imply a comparison between GPS solutions. The NASA database and the REVEL model have probably dif5 ferent results (e.g. vertical motions estimations or order of magnitude of uncertainties), but we utilized both their results, using the updated vertical data of the first, and the accurate evaluation of the horizontal relative motion of the second. Using this method, we tried to cover most of the plate boundaries for a global analysis.

About subduction zones, we selected stations along the Western Pacific and South 10 Asia boundaries, using for the horizontal velocity analysis several relative motion parameters, Pacific plate motion (PA) with respect Philippine $(\mathrm{PH})$, Okhotsk (OK) with respect to Pacific (PA), Philippine (PH) relative to Pacific (PA) and to Sunda (SU), and Australia (AU) with respect to Sunda (SU). Then we studied other convergent margins, and we chose stations along the South Western Pacific boundary, North Eastern Pa15 cific, Peru - Chile trench and Himalayan Collision zone, respectively using motion of Australia (AU) relative to Pacific (PA), North America (NA) relative to the Pacific (PA), Nazca (NZ) relative to South America (SA) and Eurasia (EU) with respect to India (IN) (Figs. 1 and 2).

About rift zones, we studied motion of GPS stations close to the Atlantic Ridge, com20 puting the relative horizontal motion with the angular vectors of Eurasia (EU) relative to North America (NA) and Africa-Nubia (NU) relative to South America (SA). Then we considered also the East Pacific Rise and the Indian Ridge, respectively using motion parameters of Nazca (NZ) relative to Pacific (PA) and Australia (AU) with respect to Somalia (SO) (Figs. 1 and 2).

25 The negative and positive signs indicate relative horizontal contraction and extension respectively (Table 1 ).

Though vertical rates from GPS data have greater error values than horizontal rates, sometimes comparable with the rate value (e.g. ASC1, Ascension Island), the comparison results (Table 1 and Fig. 3 ) show that relative horizontal motions are steadily

1, 63-80, 2006

Horizontal versus vertical plate motions

M. Cuffaro et al.

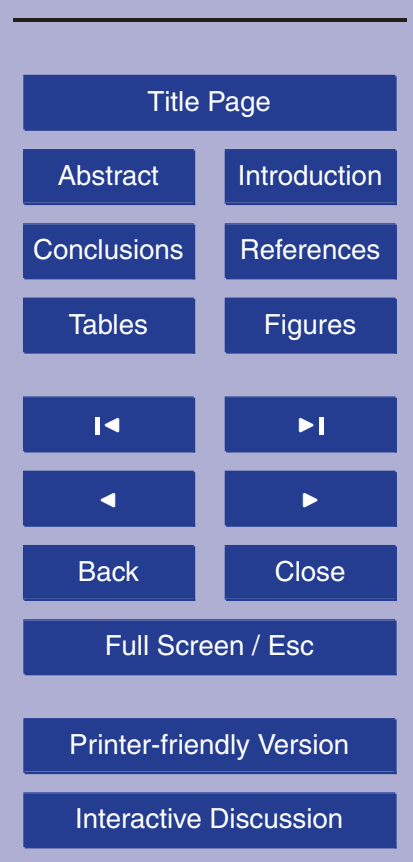


10 or 100 times faster than vertical motions. Relative horizontal motions have rates of $18.787-140.281 \mathrm{~mm} / \mathrm{yr}$, whereas vertical motions have on large-scale rates of 0.170 $10.670 \mathrm{~mm} / \mathrm{yr}$.

We did not separate vertical movements related to isostatic rebound generated by 5 erosion or subsidence due to sedimentary loading.

For past movements, magnetic anomalies record spreading rates along oceanic rifts and the stratigraphic record helps to unravel with sufficient accuracy the rates of vertical movements, computed with subsidence curves in basinal settings, or apatite fission tracks of uplifting areas, and other techniques.

10 Plate motions are a consequence of the lithosphere-mantle interaction, and the relative plate motion might not have the same velocity occurring between lithosphere and mantle. For example the "absolute" motion computed in the hotspot reference frame (Gripp and Gordon, 2002) may give faster velocities of plates relative to the mantle than relative to each other, albeit of the same order of magnitude.

15 Vertical movements along subduction zones such as uplift in the overriding plate and subsidence in the subducting plate generate respectively the growth of an orogen and the deepening of a foredeep basin. Bernet et al. (2001), use apatite fission-track grain-age distributions for detrital zircons to infer a steady-state exhumation in the Alps at rates of $0.4-0.7 \mathrm{~mm} / \mathrm{yr}$ since at least $15 \mathrm{Ma}$. Subsidence rates in the alpine foredeep are in the order of $0.1-0.3 \mathrm{~mm} / \mathrm{yr}$ (Doglioni, 1994). Rates along the Andean subduction zone are of the order of $1-4 \mathrm{~mm} / \mathrm{yr}$ for uplift and less than $0.5 \mathrm{~mm} / \mathrm{yr}$ for subsidence. Fission-track analysis in the Peruvian Andes suggests $1.1 \mathrm{~mm} / \mathrm{yr}$ uplift (Montario, 2001). Convergence rates along the same subduction zone are in the order of $30-100 \mathrm{~mm} / \mathrm{yr}$.

25 In Alaska, exhumation rates of about $3 \mathrm{~mm} / \mathrm{yr}$ have been suggested (Spotila et al., 2004). Faster (5-10 mm/yr) uplift rates have been computed in Taiwan and Papua New Guinea (Dadson et al., 2003; Baldwin et al., 2004).

Foredeeps and trenches during the last $100 \mathrm{Ma}$ have worldwide subsidence rates spanning on average from 0.1 to $1.6 \mathrm{~mm} / \mathrm{yr}$ (Doglioni, 1994), with the fastest rates
$1,63-80,2006$

Horizontal versus vertical plate motions

M. Cuffaro et al.

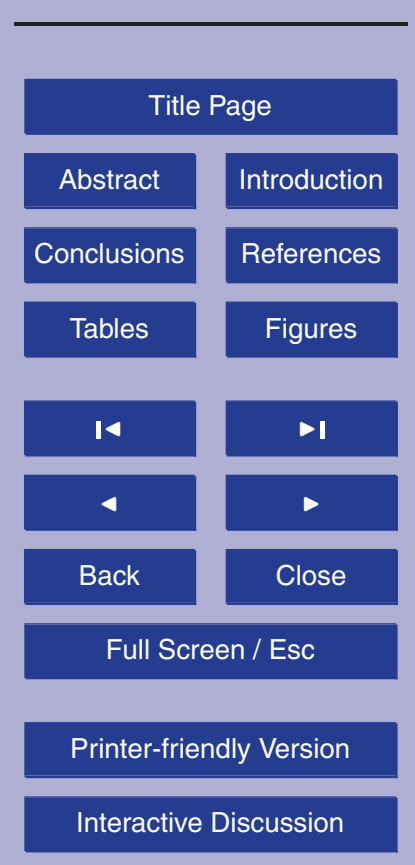


located along the west-directed subduction zones. Along the Marianas subduction zone, where the slab pull is theoretically the highest on Earth, the Pacific plate moves WNW-ward faster than $100 \mathrm{~mm} / \mathrm{yr}$, whereas the subsidence in the trench is in the order of few $\mathrm{mm} / \mathrm{yr}$ maximum.

5 If plate velocity is controlled by slab pull, how is it possible for the fastest down going plate to have such relatively smaller subsidence rate, even if it is the fastest subsidence rate of any geodynamic setting?

In extensional settings, subsidence rates determined by lithosphere stretching and thermal cooling are in the order of $0.02-0.5 \mathrm{~mm} / \mathrm{yr}$ in passive continental margins, 10 backarc settings and oceanic embayments (Doglioni, 1995). Flexural isostatic response to lithosphere stretching produces rift flank uplift; In the Northern Ethiopian plateau the maximum flank uplift rates are around 0.5-1 mm/yr (Faure, 1975). In oceanic basins, a progressive deepening of the sea floor away from the ridges is observed. This subsidence, controlled by cooling and contraction of the lithosphere em15 placed at ridges, is proportional to the square root of floor age and occurs with rates around 0.04-0.1 mm/yr (Parsons and Sclater, 1977).

Horizontal velocities are more variable. The break-up, i.e., the transition from continental rifting to oceanic rifting and drifting, marks a strong acceleration of the horizontal velocity, suddenly shifting from about $0.1 \mathrm{~mm} / \mathrm{yr}$ for the continental rift, to $10-100 \mathrm{~mm} / \mathrm{yr}$ for the oceanic spreading as computed with the magnetic anomalies (Cande and Kent, 1995). This anomalous increase in speed needs to be explained. One possibility is the decrease in coupling between lithosphere and mantle once the continental lithosphere is broken apart. The spreading rates were also used for the computation of the relative plate kinematic models for a period of 3-10 Ma (DeMets et al., 1990, 1994). During rifting, the uplift of the mantle beneath oceanic ridges compensating the volume of stretched lithosphere may have comparable velocity in order of magnitude to spreading rates (Bonatti et al., 2003).

In strike-slip settings, either subsidence or uplift can occur. Along transform boundaries, oceanic crust slices of different ages (and hence different depths) are juxtaposed,

\section{Horizontal versus vertical plate motions \\ M. Cuffaro et al.}

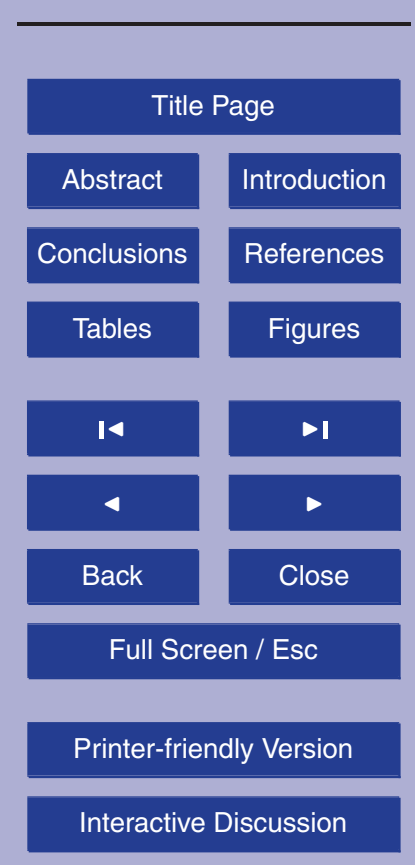


producing fault scarps. Hence vertical motion along transform faults results from differences in thermal subsidence and has therefore rates comparable to those for oceanic floor thermal subsidence.

However, compressional or tensional stresses resulting from small changes in the 5 direction of spreading can lead to uplift or additional subsidence. For example, episodic compression and extension occurred in the St Peter-Paul Island (Bonatti, 1978). Uplift of transverse ranges along the Romanche fracture zone was followed by subsidence with rates of $0.2 \mathrm{~mm} / \mathrm{yr}$ (Bonatti, 1978). In contrast, most horizontal velocities along transform boundaries range between 10 and $100 \mathrm{~mm} / \mathrm{yr}$.

10 Transcurrent margins can be characterized by uplift and subsidence, depending on the orientation of the fault with respect to the plate motion or on the departure of the fault from a simple linear trend. In pull apart basins of California, subsidence can initially occur with rates up to $2 \mathrm{~mm} / \mathrm{yr}$ due to local extension and continue with far lower rates due to cooling (Pitman and Andrews, 1985). In the Californian coastal ranges, bedrock and surface uplift from fission track studies are respectively of the order of 0.85 and $0.2 \mathrm{~mm} / \mathrm{yr}$ (Ducea et al., 2003). Horizontal rates along the San Andreas fault are constrained by geodetic studies to about $40 \mathrm{~mm} / \mathrm{yr}$ (Heflin et al., 2006). In transpressional subduction margins, such as the New Zealand Southern Alps, uplift occurs with rates of $1-3 \mathrm{~mm} / \mathrm{yr}$, as determined from the position of marine terraces (Berryman, 1993), whereas the horizontal velocity is $45 \mathrm{~mm} / \mathrm{yr}$.

Dynamic topography (either subsidence or uplift) is also characterized by slow rates in cratonic or intraplate areas. Exceptions to the general rule can be post-glacial rebound that can be faster than $10 \mathrm{~mm} / \mathrm{yr}$ (Larsen et al., 2004), or post-seismic uplift of even $80 \mathrm{~mm} / \mathrm{yr}$ after gigantic earthquakes (Freymueller et al., 2000).

The kinematics of subduction zones show that the convergence rate can be slower or faster than the subduction rate as a function of the subduction hinge migrating away or toward the upper plate (Doglioni et al., 2006). For example, along the Andean subduction, the subduction hinge migrates toward the upper plate. The convergence rate of say $68 \mathrm{~mm} / \mathrm{yr}$ is partitioned into $35 \mathrm{~mm} / \mathrm{yr}$ of shortening in the upper plate South
$1,63-80,2006$

Horizontal versus vertical plate motions

M. Cuffaro et al.

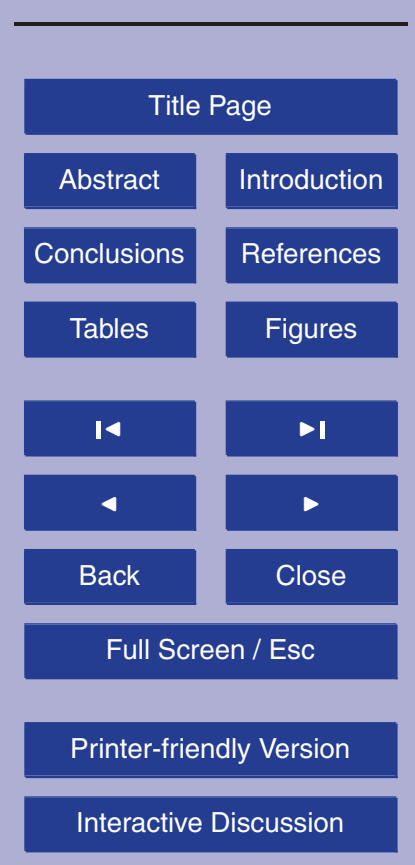


America, and $33 \mathrm{~mm} / \mathrm{yr}$ of subduction rate. Since the subduction rate is slower than the convergence rate, it is evident that the subduction is not the driving mechanism for determining the velocity of the Nazca and South America plates, but it is rather a passive feature.

\section{Conclusions}

All types of tectonic-geodynamic settings at plate boundaries show a much faster horizontal velocity with respect to the vertical motion. Is this a trivial observation, or is it rather telling us something fundamental on the dynamics of plate tectonics? Slower vertical motion implies strain partitioning and passive role of plate boundaries?

10 A comparison between horizontal and vertical motions does not allow to state which plate tectonics driving mechanism prevails. However, the steady 1 or 2 order of magnitude faster horizontal over vertical motion points for a stronger tangential component in plate tectonics than previously inferred.

Regardless the Rayleigh number that can be computed for the upper mantle con15 vection, ridges and subduction zones alone activate convection (Anderson, 2001), because the asthenosphere uplifts along rifts, and the lithosphere sinks with slabs. However, if ridges and subduction zones trigger convection, but are nevertheless still passive features, what moves plates?

The mechanisms driving plate motion, e.g., plates driven by "the boundary forces", 20 slab pull (e.g., Anderson, 2001) and ridge push versus plates actively dragged by the asthenosphere flow (e.g., Bokelmann, 2002) seems not relevant to the preceding discussion of horizontal vs. vertical motion rates, because the rates themselves do not provide evidence for or against any particular mechanism. Both "active plates and passive asthenosphere" and "an active asthenospheric flow dragging passive plates" may
$1,63-80,2006$

Horizontal versus vertical plate motions

M. Cuffaro et al.

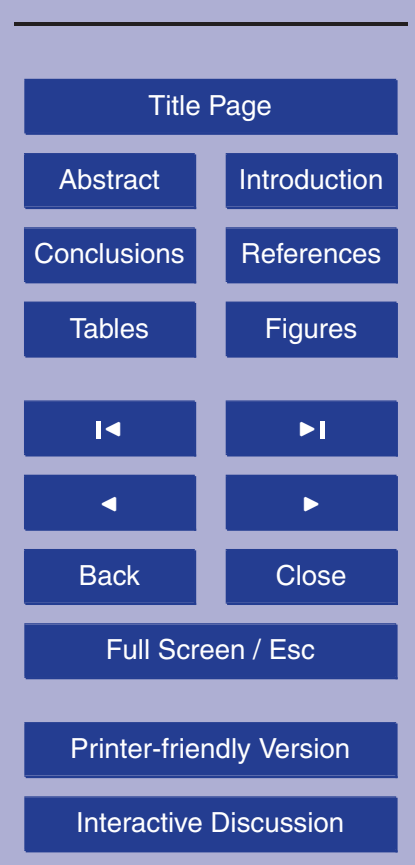


Relatively small forces can move a floating plate fast horizontally, because no work has to be done against gravity, whereas non-isostatic vertical motions require work to be done against gravity. However this can be true when at the base of the lithosphere there is a very low viscosity in the decoupling layer, i.e., the weaker low velocity zone 5 in the upper asthenosphere. Increasing the asthenosphere viscosity, larger forces are required to decouple the lithosphere. On the other hand, if the lithosphere is not moved by lateral forces such as the slab pull, but rather passively dragged by the mantle, the higher viscosity will enable a better coupling, but then what is generating the decoupling of the lithosphere? Are there external tangential forces acting on the lithosphere?

The main forces acting on the lithosphere can be subdivided into coupled and uncoupled forces. Mantle drag and trench suction need high coupling between the lithosphere and the asthenosphere to be more effective (higher viscosity at the lithosphere base). The ridge push, the slab pull and the tidal drag should rather need low coupling to be efficient (lower viscosity at the lithosphere base, Fig. 4). Unlike the boundary 5 force such as the slab pull, the tidal drag has the advantage to be a volume force, acting simultaneously on the whole plate. Lateral variations in the low-velocity layer viscosity could control the different velocity of plates.

Are plates dragged and sheared at the base by a faster moving mantle (Bokelmann, 2002)? However, whatever the mantle convection works, it cannot explain the lithosphere decoupling alone. Are then plates rather pulled by slab pull forces (Anderson, 2001)? Could they be driven by Earth's rotation and tidal drag (Scoppola et al., 2006)? Are plates moved by a combination of the aforementioned mechanisms?

Acknowledgements. Critical reading by S. Stein was very constructive. Discussions with E. Bonatti, M. Crespi, F. Riguzzi and M. Ligi were very inspiring. Many of the figures were 25 made with the Generic Mapping Tools of Wessel and Smith (1995).
$1,63-80,2006$

Horizontal versus vertical plate motions

M. Cuffaro et al.

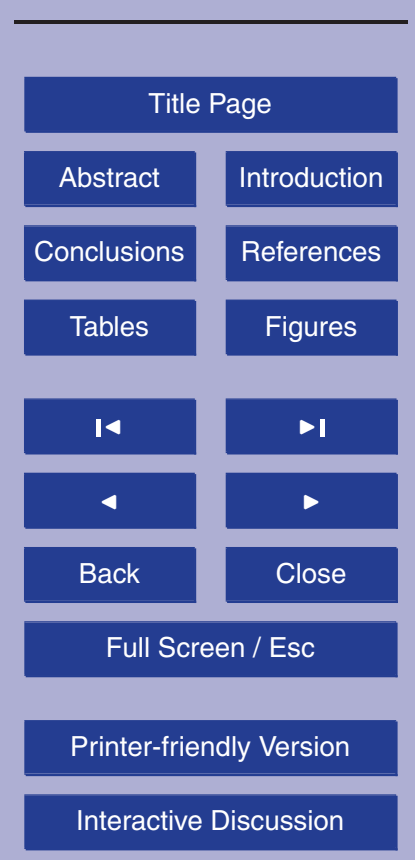




\section{References}

Altamimi, Z., Sillard, P., and Boucher, C.: ITRF2000: a new release of the international terrestrial reference frame for earth sciences applications, J. Geophys. Res., 107(B10), 2214, doi:10.1029/2001JB000561, 2002.

5 Anderson, D. L.: Topside tectonics, Science, 293, 2016-2018, 2001.

Baldwin, S. L., Monteleone, B. D., Webb, L. E., Fitzgerald, P. G., Grove, M., and Hill, E. J.: Pliocene eclogite exhumation at plate tectonic rates in eastern Papua New Guinea, Nature, 431, 263-267, 2004.

Bernet, M., Zattin, M., Garver, J. I., Brandon, M. T., and Vance, J. A.: Steady-state exhumation of the European Alps, Geology, 29, 35-38, 2001.

Berryman, K. R.: Distribution, age, and deformation of late Pleistocene marine terraces at Mahia Peninsula, Hikurangi subduction margin, New Zealand, Tectonics, 12, 1365-1379, 1993.

Bevis, M., Taylor, F. W., Schutz, B. E., Recy, J., Isacks, B. L., Helu, S., Singh, R., Kendrick, E., Stowell, J., Taylor, B., and Calmant, S.: Geodetic observations of very rapid convergence and back-arc extension at the Tonga arc, Nature, 374, 249-251, 1995.

Bokelmann, G. H. R.: Which forces drive North America?, Geology, 30, 1027-1030, 2002.

Bonatti, E.: Vertical tectonism in oceanic fracture zones, Earth Planet. Sci. Lett., 37, 369-379, 1978.

20 Bonatti, E., Ligi, M., Brunelli, D., Cipriani, A., Fabretti, P., Ferrante, V., Gasperini, L., and Ottolini, L.: Mantle thermal pulses below the Mid-Atlantic Ridge and temporal variations in the formation of oceanic lithosphere, Nature, 423, 499-505, 2003.

Cande, S. C. and Kent, D. V.: Revised calibration of the geomagnetic time scale for the late Cretaceous and Cenozoic, J. Geophys. Res., 100, 6093-6095, 1995.

25 Dadson, S. J., Hovius, N., Chen, H., Dade, B., Hsieh, M. L., Willett, S. D., Hu, J. C., Horng, M. J., Chen, M. C., Stark, C. P., Lague, D., and Lin, J. C.: Links between erosion, runoff variability and seismicity in the Taiwan orogen, Nature, 426, 648-651, 2003.

DeMets, C., Gordon, R. G., Argus, D. F., and Stein, S.: Current plate motions, Geophys. J. Int., 101, 425-478, 1990.

30 DeMets, C., Gordon, R. G., Argus, D. F., and Stein, S.: Effect of recent revisions to the geomagnetic reversal time scale on estimates of current plate motions, Geophys. Res. Lett., 21, 2191-2194, 1994. 
Doglioni, C.: Foredeeps versus subduction zones, Geology, 22, 271-274, 1994.

Doglioni, C.: Geological remarks on the relationships between extension and convergent geodynamic settings, Tectonophysics, 252, 253-267, 1995.

Doglioni, C., Carminati, E., and Cuffaro, M.: Simple kinematics of subduction zones, Int. Geol. Rev., 48/6, 479-493, 2006.

Ducea, M., House, M. A., and Kidder, S.: Late Cenozoic denudation and uplift rates in the Santa Lucia mountains, California, Geology, 31, 139-142, 2003.

Faure, H.: Recent crustal movements along the Red Sea Gulf of Aden coasts in Afar (Ethiopia and TFAl), Tectonophysics, 29, 479-486, 1975.

10 Freymueller, J. T., Cohen, S. C., and Fletcher, H.: Variations in present-day deformation, Kenai Peninsula, Alaska, and their implications, J. Geophys. Res., 105, 8079-8101, 2000.

Gordon, R. G.: Diffuse oceanic plate boundaries: strain rates, vertically averaged rheology, and comparison with narrow plate boundaries and stable plate interiors, AGU, Geophys. Monogr., 121, 143-159, 2000.

Gordon, R. G. and Stein, S.: Global tectonics and space geodesy, Science, 256, 333-342, 1992.

Gripp, A. E. and Gordon, R. G.: Young tracks of hotspots and current plate velocities, Geophys. J. Int., 150, 321-364, 2002.

Heflin, M., et al.: http://sideshow.jpl.nasa.gov/mbh/series.html, 2006.

Larsen, C. F., Motyka, R. J., Freymueller, J. T., Echelmeyer, K. A., and Ivins, E. R.: Rapid uplift of southern Alaska caused by recent ice loss, Geophys. J. Int., 158, 1118-1133, doi:10.1111/j.1365-246X.2004.02356.x, 2004.

Montario, M. J.: Exhumation of the Cordillera Blanca, Northern Peru, based on apatite fission track analysis, Department of Geology, Union College, Schenectady, New York, Thesis, 252001.

Parsons, B. and Sclater, J.: An analysis of the variation of ocean floor bathymetry and heat flow with age, J. Geophys. Res., 82, 803-827, 1977.

Pitman, W. C. and Andrews, J. A.: Subsidence and thermal history of small pull apart basins, Spec. Publ. Soc. econ. Paleont. Mineral., 37, 45-49, 1985.

30 Scoppola, B., Boccaletti, D., Bevis, M., Carminati, E., and Doglioni, C.: The westward drift of the lithosphere: a rotational drag?, Bull. Geol. Soc. Am., 118(1/2), doi:10.1130/B25734.1, 2006.

Sella, G. F., Dixon, T. H., and Mao, A.: REVEL: A model for recent plate velocity from space 
geodesy, J. Geophys. Res., 107(B4), 2081, doi:10.1029/2000JB000033, 2002.

Spotila, J. A., Buscher, J. T., Meigs, A. J., and Reiners, P. W.: Long-term glacial erosion of active mountain belts: Example of the Chugach-St. Elias Range, Alaska, Geology, 32, 501-504, 2004.
1, 63-80, 2006

\section{Horizontal versus} vertical plate motions

M. Cuffaro et al.

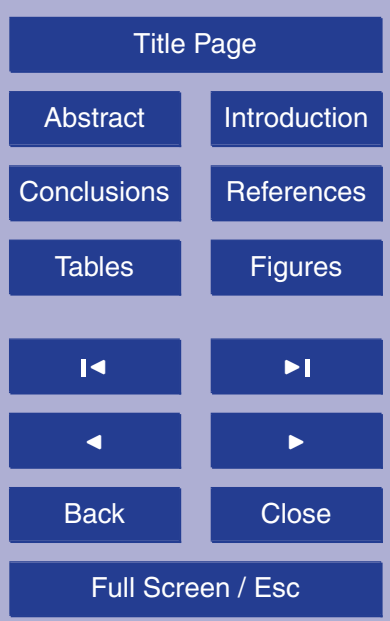

Printer-friendly Version

Interactive Discussion 
Table 1. Present horizontal vs. vertical plate motions from GPS data. See text for explanations.

\begin{tabular}{|c|c|c|c|c|c|}
\hline \multirow[b]{2}{*}{ GPS Station $^{a}$} & \multicolumn{2}{|c|}{ Position } & \multirow[b]{2}{*}{ Plate Pair $^{b}$} & \multicolumn{2}{|c|}{$\begin{array}{l}\text { Rate } \pm 1 \sigma \\
\left(\mathrm{mm} \mathrm{yr}^{-1}\right)\end{array}$} \\
\hline & $\mathrm{N}$ & E & & Horizontal Motion & Vertical Motion \\
\hline \multicolumn{6}{|c|}{ Western Pacific and South Asia } \\
\hline GUAM & 13.58 & 144.86 & PA-PH & $-18.787 \pm 3.204$ & $3.810 \pm 0.150$ \\
\hline TSKB & 36.10 & 140.08 & OK-PA & $-72.018 \pm 14.862$ & $0.270 \pm 0.080$ \\
\hline PETP & -31.80 & 115.88 & OK-PA & $-78.027 \pm 14.399$ & $-1.990 \pm 0.190$ \\
\hline PIMO & 14.63 & 121.07 & PH-SU & $-102.291 \pm 7.840$ & $0.920 \pm 0.350$ \\
\hline BAKO & -6.49 & 106.84 & AU-SU & $-64.061 \pm 1.579$ & $5.700 \pm 0.400$ \\
\hline \multicolumn{6}{|c|}{ South Western Pacific } \\
\hline NOUM & -22.26 & 166.41 & AU-PA & $-79.479 \pm 1.087$ & $5.030 \pm 0.160$ \\
\hline AUCK & -36.60 & 174.83 & AU-PA & $-52.268 \pm 1.072$ & $2.010 \pm 0.090$ \\
\hline MAC1 & -54.49 & 158.93 & AU-PA & $-32.096 \pm 1.081$ & $0.910 \pm 0.080$ \\
\hline \multicolumn{6}{|c|}{ North Eastern Pacific } \\
\hline KODK & 57.73 & -152.50 & NA-PA & $-59.274 \pm 0.814$ & $7.820 \pm 0.290$ \\
\hline UCLU & 48.92 & -125.54 & NA-PA & $-46.786 \pm 0.847$ & $3.840 \pm 0.230$ \\
\hline $\operatorname{coso}$ & 35.98 & -117.80 & NA-PA & $-48.885 \pm 0.849$ & $-3.670 \pm 0.190$ \\
\hline \multicolumn{6}{|c|}{ Peru-Chile Trench } \\
\hline RIOP & -1.65 & -78.65 & NZ-SA & $-57.524 \pm 2.606$ & $4.240 \pm 1.150$ \\
\hline AREQ & -16.46 & -71.49 & NZ-SA & $-66.430 \pm 2.387$ & $3.180 \pm 0.920$ \\
\hline UNSA & -24.72 & -65.40 & NZ-SA & $-69.339 \pm 2.387$ & $1.660 \pm 0.380$ \\
\hline SANT & -33.15 & -70.66 & NZ-SA & $-70.299 \pm 2.246$ & $4.360 \pm 0.060$ \\
\hline \multicolumn{6}{|c|}{ Himalayan Collision Zone } \\
\hline KIT3 & 39.13 & 66.88 & EU-IN & $-28.736 \pm 8.568$ & $-1.830 \pm 0.090$ \\
\hline $\begin{array}{l}\text { LHAS } \\
\text { Attantic Ridae }\end{array}$ & 29.65 & 91.10 & EU-IN & $-36.789 \pm 8.029$ & $1.230 \pm 0.110$ \\
\hline $\begin{array}{l}\text { Atlantic RIdge } \\
\text { REYK }\end{array}$ & 64.13 & -21.95 & EU-NA & $19.897 \pm 0.498$ & -3.160 \\
\hline ASC1 & -7.95 & -14.41 & NU-SA & $29.567 \pm 1.069$ & $0.170 \pm 0.140$ \\
\hline GOUG & -40.34 & -9.88 & NU-SA & $29.580 \pm 1.043$ & $-10.670 \pm 0.240$ \\
\hline \multicolumn{6}{|c|}{ East Pacific Rice } \\
\hline GALA & -0.74 & -90.30 & NZ-PA & $117.082 \pm 2.444$ & $-1.780 \pm 0.200$ \\
\hline $\begin{array}{l}\text { EISL } \\
\text { Indian }\end{array}$ & -27.14 & -109.38 & NZ-PA & $140.281 \pm 2.211$ & $0.250 \pm 0.110$ \\
\hline DGAR & -7.26 & 72.37 & AU-SO & $36.331 \pm 8.596$ & $1.720 \pm 0.180$ \\
\hline
\end{tabular}

$1,63-80,2006$

\section{Horizontal versus vertical plate motions}

M. Cuffaro et al.

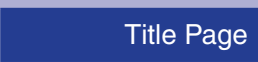

\section{Abstract Introduction \\ Conclusions References}

\section{Tables \\ Figures}
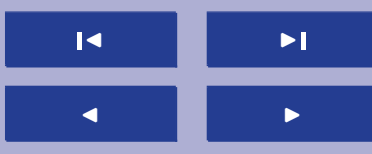

Back

Close

Full Screen / Esc

Printer-friendly Version

Interactive Discussion

a AREQ Arequipa - Peru, ASC1 Ascension Island, AUCK Whangaparaoa Peninsula - New Zealand, BAKO Cibinong - Indonesia, COSO Coso Junction USA, DGAR Diego Garcia Island - UK Territory, EISL, Easter Island - Chile, GALA Galapagos - Ecuador, GOUG Gough Island - dependent territory of the UK, GUAM Dededo - Guam, KIT3 Kitab - Uzbekistan, KOKD Kodiak - USA, LHAS Lhasa - China, MAC1 MacQuarie Island, Sub-Antarctic - Southern Ocean, NOUM Noumea - France, PETP Petropavlovsk-Kamchatka - Russian Federation, PIMO Quezon City - Phillipines, REYK Reykjavik - Iceland, RIOP Riobamba - Ecuador, SANT Santiago - Chile, TSKB Tsukuba - Japan, UCLU Ucluelet - Canada, UNSA Salta - Argentina.

${ }^{b}$ The first plate rotates counterclockwise relative to the second and vicecersa. AU - Australia, EU - Eurasia, IN - India, NA - North America, NU - Nubia, NZ

- Nazca, OK - Okhotsk, PA - Pacific, PH - Philippine, SA - South America, SO - Somalia, SU - Sunda. 


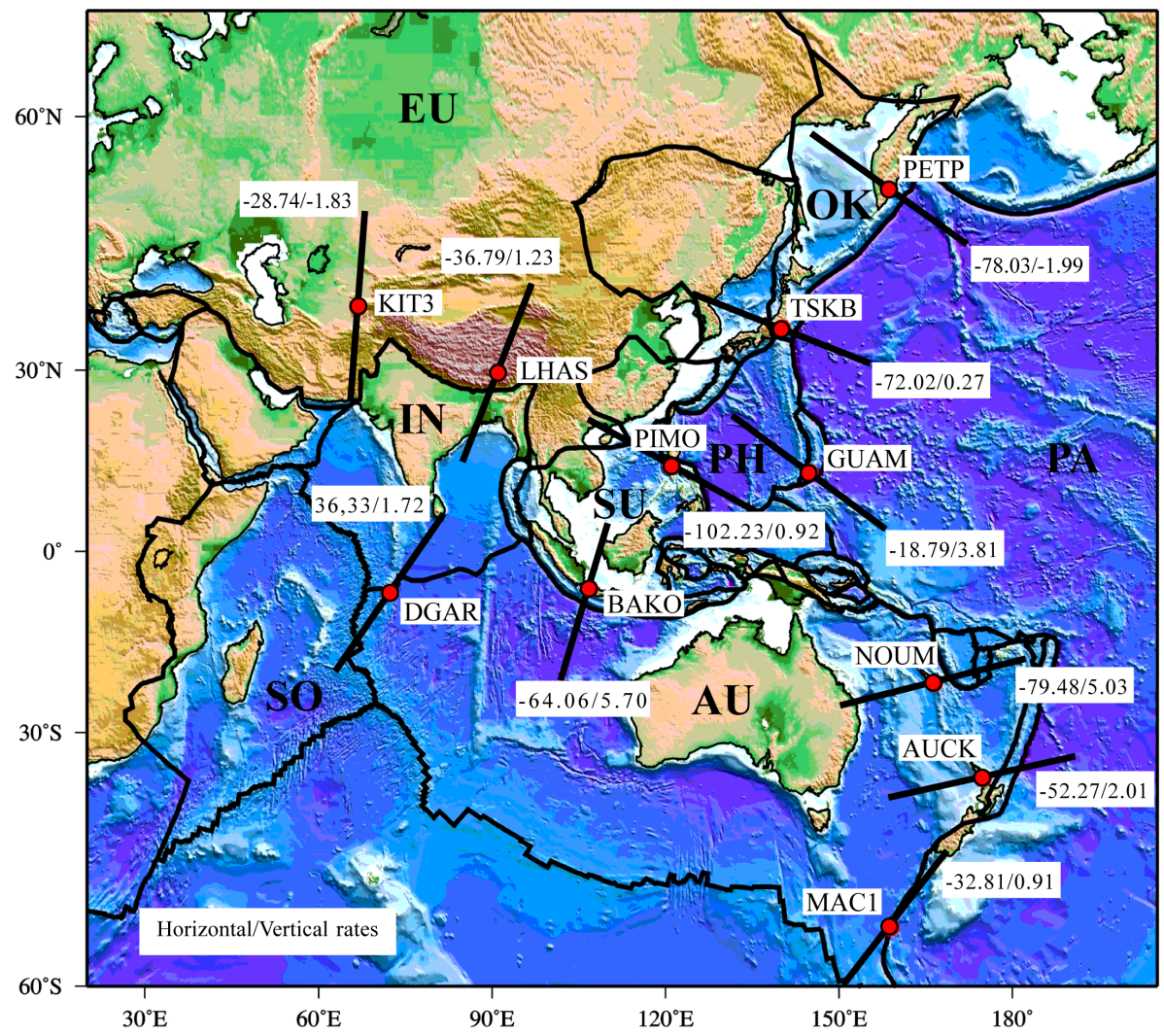

Fig. 1. Comparisons between relative horizontal and vertical motions of selected GPS stations for paths in the Western Pacific and South Asia, South Eastern Pacific, Himalaya and Indian Ridge. Oriented segments show relative motion directions. Units are in $\mathrm{mm} / \mathrm{yr}$, and show horizontal and vertical velocities respectively. The dot indicates the location of the vertical motion on the plate boundary. About horizontal velocities, negative signs show contraction and positive signs show extension. About vertical velocities, negative signs show subsidence and positive signs show uplift.
$1,63-80,2006$

Horizontal versus vertical plate motions

M. Cuffaro et al.

Title Page

Abstract

Introduction

Conclusions

References

Tables

Figures

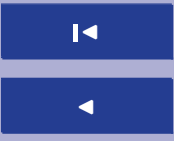

$\rightarrow$

Back

Close

Full Screen / Esc

Printer-friendly Version

Interactive Discussion 


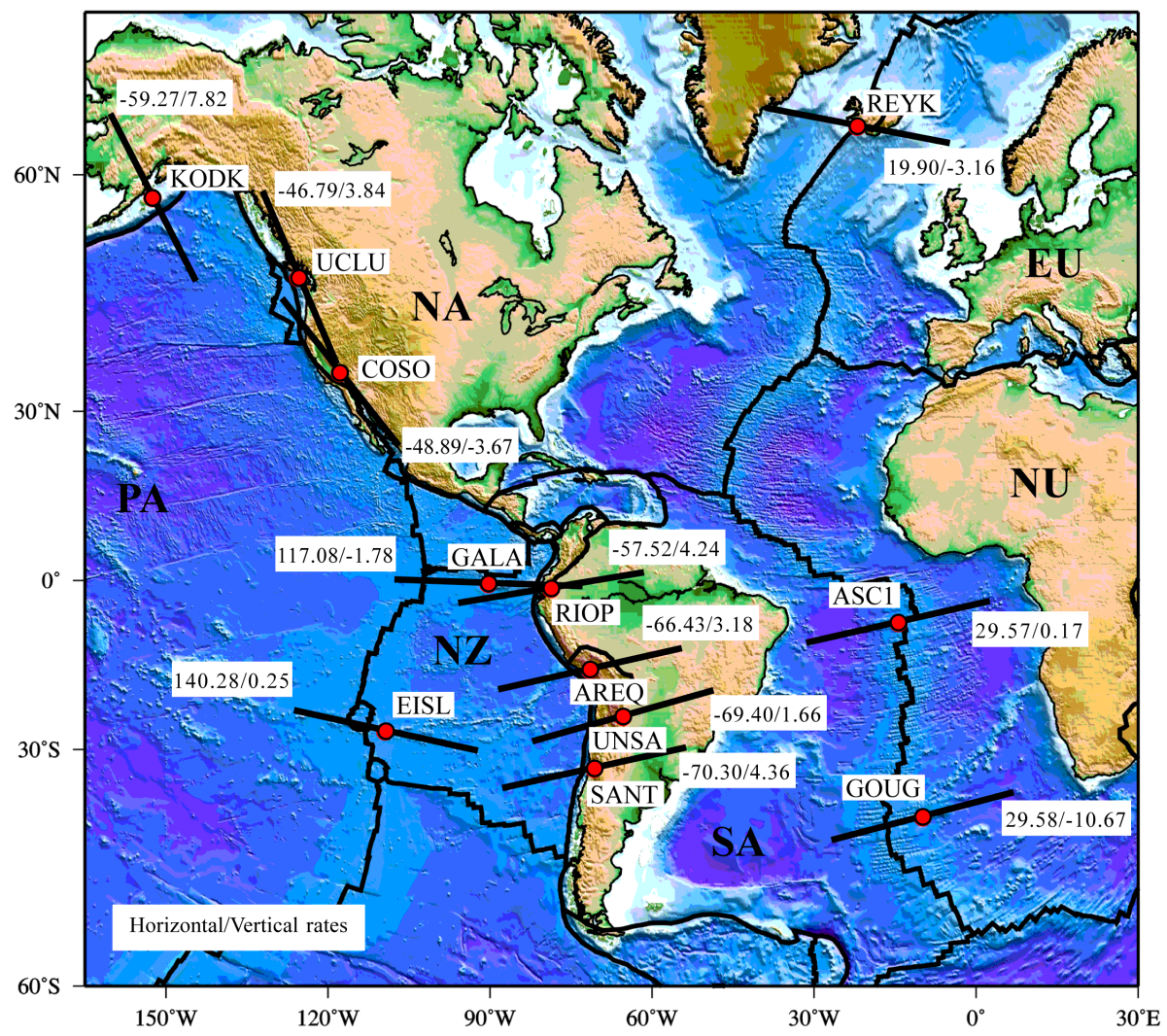

Fig. 2. Comparisons between relative horizontal and vertical motions of selected GPS stations for paths in the North Eastern Pacific, East Pacific Rice, Peru - Chile Trench and the Atlantic Ridge. Oriented segments show relative motion directions. Units are in $\mathrm{mm} / \mathrm{yr}$, and show horizontal and vertical velocities respectively. The dot indicates the location of the vertical motion on the plate boundary. About horizontal velocities, negative signs show contraction and positive signs show extension. About vertical velocities, negative signs show subsidence and positive signs show uplift.
$1,63-80,2006$

\section{Horizontal versus} vertical plate motions

M. Cuffaro et al.

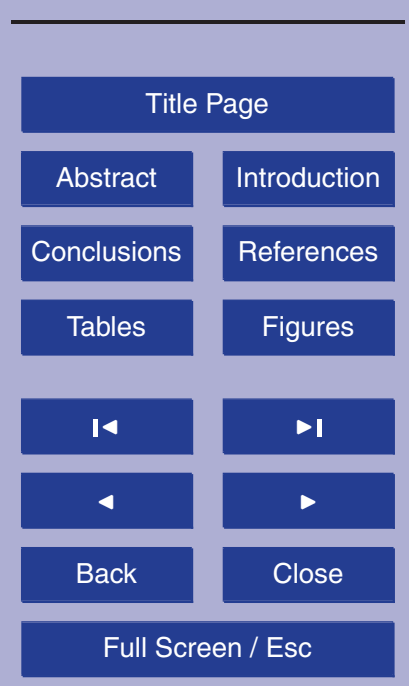

Printer-friendly Version

Interactive Discussion 


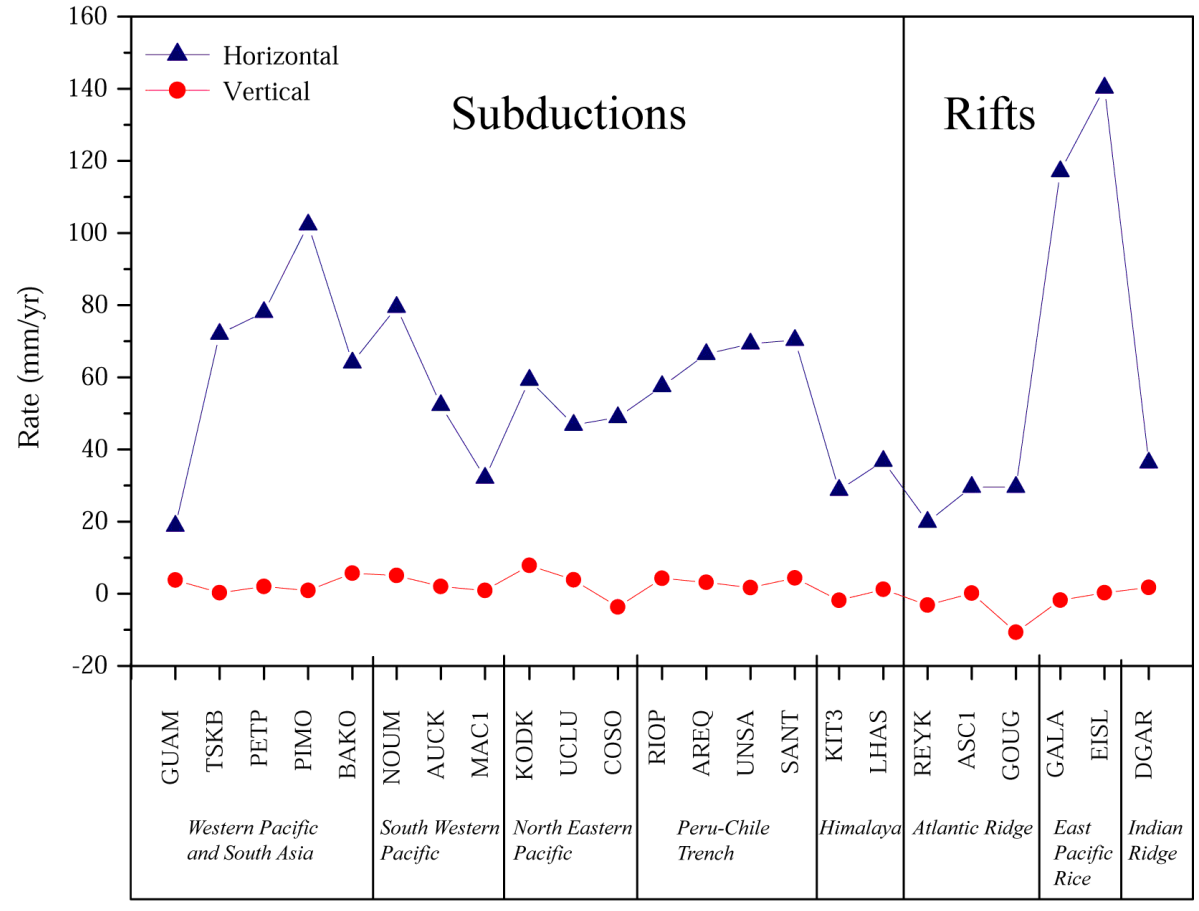

Fig. 3. Comparison of the present horizontal and vertical plate motions rates along subduction and rift zones for selected GPS stations. The horizontal rates of subduction and rift settings are plotted as absolute values, and are respectively the negative and the positive values of Figs. 1 and 2. Negative and positive vertical rates respectively indicate subsidence and uplift.
1, 63-80, 2006

\section{Horizontal versus} vertical plate motions

M. Cuffaro et al.

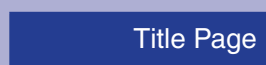

\begin{tabular}{|c|c|}
\hline Abstract & Introduction \\
\hline Conclusions & References \\
\hline Tables & Figures \\
\hline I4 & $-\mathbf{1}$ \\
\hline 4 & $\triangleright$ \\
\hline Back & Close \\
\hline Full Screen / Esc \\
\hline
\end{tabular}

Printer-friendly Version

Interactive Discussion 


\section{Horizontal versus} vertical plate motions

M. Cuffaro et al.

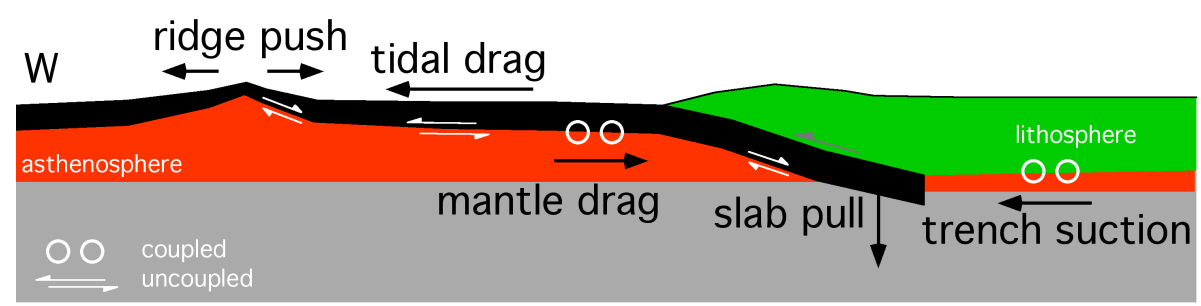

Fig. 4. Main forces acting on the lithosphere. Mantle drag and trench suction need high coupling (higher viscosity) between lithosphere and asthenosphere to be more effective. Ridge push, slab pull and tidal drag should rather need low coupling (lower viscosity) to be efficient. Since the lithosphere is decoupled with respect to the asthenosphere, possibly more than one force is actively forcing plate motions. Circles indicate coupled forces, white half arrows show the uncoupled forces. See text.

Title Page

Abstract Introduction

Conclusions

References

Tables

Figures

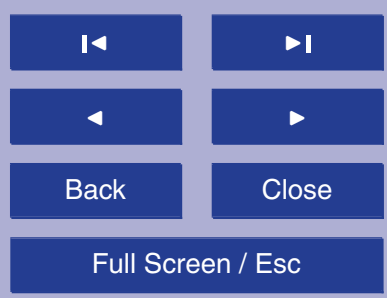

Printer-friendly Version

Interactive Discussion 